\section{P. Garrod}

LAWrence Paul Garrod, emeritus professor of bacteriology in the University of London died on 11 September 1979, aged 84. He was born on 7 September 1895. After school at Sidcot, Garrod's medical training at King's College, Cambridge and St. Bartholomew's Hospital was interrupted by service in 1917 and 1918 as a Surgeon Sub-Lieutenant, RNVR. At Bart's, his career as a student was outstanding and he won the Senior Scholarship in Medicine. In due course, after qualification, he became Chief Assistant to Dr Morley Fletcher and at that stage he seemed bound for the staff of the hospital as a consultant physician. But in 1925 he turned to pathology and then bacteriology, being appointed Professor of Bacteriology in the University of London in 1936, a post which he held with that of Bacteriologist to the hospital, until his retirement in 1961.

At Bart's he was a familiar and much respected figure. To the thousands of Bart's doctors who were taught by him during his time, he will probably best be remembered for his lectures and the associated practical classes at which he was a meticulous attender. A very clear logical speaker, his lectures were illustrated by a series of anecdotes and comments that held the attention of his students. To the hospital staff, his wide clinical and laboratory experience was always available. His opinion was always worth having and was much sought.

To a much larger audience, Garrod was known for his research and for his writing. Before the last war he became interested in disinfection and sterilisation, a subject that attracts the interest of few doctors, and he rapidly became one of the leading authorities in the country, with his name attached to one of the standard tests for disinfectants. This early experience stood him in good stead with the discovery of sulphonamides and then antibiotics, and a flow of papers began from his laboratory, many with his assistant, Miss Pamela Waterworth, dealing with chemotherapy in general and the properties and uses of each new antibiotic as it emerged. He played an important part in the Medical Research Council's trial of the penicillin treatment of subacute bacterial endocarditis, that was to set the pattern for many subsequent clinical trials.

As a writer, Garrod's contributions, both recognized and anonymous, were immense. He edited the British Journal of Experimental Pathology for many years and his close association with the British Medical Journal ran from 1931 until he died; he served on various committees and was at one time Chairman of the BMJ Journal Committee. When he retired from Bart's, the then Editor of the British
Medical Journal, writing in the Hospital Journal, said that "it is difficult for me to say just how much we on the staff of the BMJ - and its readers - owe to Garrod. He has written book reviews, leading articles, annotations, answers to questions, all with effortless ease, precision of style, accuracy of fact, and a certain marked honesty that has been vastly refreshing."

Apart from his other writing, he was coauthor of three books. First, before the war, Recent Advances in Pathology with Geoffrey Hadfield and then after the war, Antibiotic and Chemotherapy, first with Mary Barber and later with Francis O'Grady, and Hospital Infection with R.E.O. Williams and others. Retirement did not slow his pen, and he continued his work for the BMJ as well as answering the many invitations to speak that he received from this country, Europe and the United States.

Professional recognition came his way by honours and appointments. His views were sought as a committee member by the Department of Health, the Medical Research Council and World Health Organization. He examined for the Universities of London, Oxford and Cambridge. He was president of his section of the Royal Society of Medicine, VicePresident of the British Medical Association, President of the Institute of Medical Laboratory Technology, Consultant in Antibiotics to the Army, and on retirement, Honorary Consultant in Chemotherapy to the Royal Postgraduate Medical School. The University of Louvain conferred the title of Honorary Alumnus on him, Glasgow awarded him an Honorary Doctorate of Law and the Royal College of Pathologists elected him an Honorary Fellow.

\section{R.A. Shooter}

\section{John Raymont}

THE sudden death of Professor J.E.G. Raymont on 30 August 1979, at the age of 64 , has deprived the world's community of marine scientists of a respected member and the field of zooplankton of one of its most distinguished students.

His interest in zooplankton began at University College, Exeter where he took first class honours in zoology, and was soon reinforced during 1937-38 when he held a Henry Fellowship at Harvard and spent the summer of 1937 at Woods Hole. After a brief return to Exeter as assistant lecturer he was appointed Lecturer in Zoology in Edinburgh in 1939. There, in conjunction with Sheina Marshall, F. Gross and A.P. Orr, a study was commenced on the effects on plankton and fish productivity of fertilising sea lochs, which was a precursor to marine fish farming in enclosed waters. During this period he met and married Brigit Sloan, who remained his constant companion at home and colleague at work in an enviably happy marriage.

In 1946 John Raymont moved back to the south to take up the Chair of Zoology at Southampton at the early age of 31. A generous grant from the Goldsmiths' Company enabled the purchase of the department's first boat, Aurelia, and his attention, after a brief period of working with other organisms, turned back to plankton. This was an era of public and scientific interest in the possibility of utilising plankton directly or indirectly as food organisms and he initiated long-term studies on the composition and physiology of zooplankton species. One of the researchers attracted by his studies in this field was a young Indian biologist, $\mathrm{S}$. Krishnaswamy, who subsequently collaborated with John Raymont on several occasions. Partly through this connection and partly from international prestige gained as a result of his definitive work Plankton and Productivity in the Oceans (1963), John Raymont was invited under the auspices of the Indian U.G.C. and the British Council to advise on the establishment of the Centre of Advanced Marine Studies at Porto Novo. Thus began a long association with the training of oceanographers in many lands which culminated in membership of such bodies as the I.O.C. (Training, Education and Mutual Assistance), S.C.O.R., Nuffield Tropical Marine Biology Fellowship Panel and Chairmanship of the UNESCO Advisory Panel on International Marine Biology Centres.

At Southampton his academic career was crowned by appointments as Dean of the Faculty of Science 1961-1963 and Deputy Vice Chancellor 1966-68. His real ambitions lay, however, in a somewhat different direction and these were fulfilled in 1964 with the foundation of a department devoted to the study of marine science in all its aspects. Under his skilful guidance the staff of this multidisciplinary department were welded into a coherent and integrated unit in spite of their disparate research interests. The department quickly gained the international reputation which will live on as a monument to John Raymont's skills as a quiet unifier.

His international commitments, research culminating in some 60 papers, and administration came nowhere near exhausting his energies and over the years he was inter alia an adviser to the C.E.G.B. on matters relating to warmed water release, a member of the British National Committee for Oceanic Research and the Royal Society Pollution Study Group, member of the Councils of the Fresh Water Biological Association, Marine Biological Association and National Institute of Oceanography. As Chairman of the 
Planning and Development Committee of the Wessex Regional Hospital Board and later as Vice Chairman of the Hampshire Area Health Authority, he was deeply involved in the expansion of hospital services in the area.

He was honoured by the award of the OBE in 1978 and earlier by election to a Fellowship of the Indian Academy of Sciences.

Marine scientists the world over will grieve the loss of a man who by quiet example was able to foster participation between research workers at every level, of different interests and from many nations.

A.P.M. Lockwood

\section{Jack Tizard}

Professor JACK TIZARD died in London aged sixty, on 2 August 1979, as a result of cancer found to be inoperable eight months earlier. So passed one of the foremost postwar research workers in mental retardation and child development.

Born a New Zealander, Jack graduated there and after overseas Army services undertook a postgraduate degree at Oxford where he met his wife. In 1948 he joined the Medical Research Council's Social Psychiatry Research Unit at the Institute of Psychiatry in London, and with his colleague Neil O'Connor was directed by Professor Aubrey Lewis into the neglected field of mental deficiency. He was appalled by the situation he found in hospitals for the mentally defective which in those days were used as places where socially disadvantaged young people could be put away. As a fearless man he said so, among other things challenging the medical model which was enshrined in the 1913 Mental Deficiency Act. Tizard and O'Connor set about showing that industrial habilitation leading to fairly rapid discharge from care was a viable possibility. Their pioneering studies on the mildly retarded were brought together in 1956 in an important book The Social Problem of Mental Deficiency.

However, there was more to do. There remained the moderately and severely retarded who were on the whole considered unemployable in even the simplest capacity. In a series of innovatory experiments it was shown that young adults with intelligence quotients in the thirties and forties could in certain circumstances learn, respond to incentives, retain their learning and transfer it to rather different situations. Others built upon and extended this work which cast new light on our potential for helping the more severely disabled, and their own potential for change.

Jack himself was ready to move on, and with the help of Dr Leslie Hilliard transferred a number of mentally handicapped children out of the Fountain Hospital and into a country house which resembled a boarding school. In 1961 he published The Mentally Handicapped and Their Families (with J.C. Grad) and in 1964 Community Services for the Mentally Handicapped. His belief that the quality of the social structure and organization of any community is a major determinant of development and behaviour of its members led him into the field of social policy.

In 1964 Jack was appointed to the first Chair in Child Development at the University of London; his outstanding contribution to the study of mental subnormality was acknowledged in 1968 when, jointly with Neil O'Connor, he received the Kennedy International Scientific Award, to be followed in 1973 by the annual research award of the American Association on Mental Deficiency. In the early nineteen-seventies, as Research Professor, he founded The Thomas Coram Research Unit, a unique multi-disciplinary establishment in which medical and a variety of social scientists collaborated in policy-oriented research projects. His erudition, high intelligence and unusually attractive personality ensured that he became much in demand for committee work. An excellent and incisive chairman, he was invited to act in several different capacities for a large number of organizations including the Social Science Research Council, the Department of Health and Social Security, the Association for Child Psychology and Psychiatry, the WHO Expert Committee on Mental Health, and for the British Psychological Society as president. He was appointed CBE in 1973.

Despite his generous contribution to committees, his research continued to flourish, and a steady flow of books and articles appeared over the years on a wide variety of topics relating to children. Jack Tizard was an example of that unusually effective individual, a radical thinker accepted by the Establishment.

In the final eight months, much of it in pain, Jack's bearing befitted his life. Fortitude, equanimity and hard work were his daily purposes; his courage was well matched by that of Barbara, his wife. Their long, happy marriage must have given both a background of security, and contributed in no small measure to the success each enjoyed.

To say of a man that "we shall not see his like again" is often a sentimental exaggeration; in the case of Jack Tizard, this is not the case. Those hundreds of us who knew him personally must feel a deep sense of loss at his passing.

Ann Clarke and Alan Clarke

\section{Marcel Florkin}

BORN in Liège, Belgium in the first year of the new century (15 August 1900), Marcel Florkin died in Liège on 3 May 1979. His early education and his medical degree were also at Liège, but thereafter he gained international recognition through his con- tributions in the areas of invertebrate physiology, comparative biochemistry and physiology, biochemical evolution, and origin of life, as well as through numerous roles in the development of international aspects of biochemistry.

Florkin's interest in physiology and biochemistry were increased by study in the laboratories of such eminent scientists as Joseph Barcroft, Richard Kuhn, Heinrich Wieland, and Edwin Cohn, following which he spent 36 years in teaching and research at the University of Liège, interrupted by visiting professorships at Duke University and the Universities of Washington and Oregon.

Perhaps the most compelling urge of his life in science was to extend his interests and contributions beyond ordinary limits, into broadly related areas of history, comparative aspects of physiology and biochemistry, evolution, and the nature of men who have contributed uniquely to the field of biological science. In addition to his numerous individual contributions, he undertook prodigious tasks of assembling as senior editor the world's contributions in multi-volume collections in various fields. Witness the ten volumes of Chemical Zoology, the seven volumes of Comparative Biochemistry (Florkin and Mason), and the 34 volumes of Comprehensive Biochemistry (Florkin and Stotz). The last five volumes of the latter series were devoted to the History of Biochemistry, his own contribution, and constituting written testimony to his critical and intimate knowledge of the great events in biochemistry. Included in his History is a remarkable collection of photographs of pioneers in biochemistry, itself a notable tribute to his perseverance and human touch.

Florkin contributed greatly to the role of biochemistry at the international level. In 1952 he became chairman of the International Committee of Biochemistry, and in 1955 was named the first President of the newly formed International Union of Biochemistry, following which he was instrumental in gaining admission of the newly formed Union into the International Council of Scientific Unions. As first Treasurer of the Union, the writer can attest to the diplomatic skills and warm spirit of negotiation displayed by Professor Florkin.

Marcel Florkin gained many honors and awards in his active life, including honorary membership in the Royal Institution of Great Britain and honorary fellowship in the Royal Society of Edinburgh. Yet in his busy life he maintained an active interest in the arts, and seldom missed an opportunity in his travels to find a moment for a visit to the local art museums to view their recent acquisitions. It is not surprising that he was devoted to family and close friends, who, along with many scientific colleagues, will miss his great warmth and human spirit.

Elmer H. Stotz 